\title{
Genetic Diversity Among Banana streak virus Isolates from Australia
}

\author{
A. D. W. Geering, L. A. McMichael, R. G. Dietzgen, and J. E. Thomas
}

First, second, and fourth authors: Queensland Horticulture Institute, Department of Primary Industries, 80 Meiers Road, Indooroopilly, Queensland 4068, Australia; and third author: Queensland Agricultural Biotechnology Centre, Department of Primary Industries, Gehrmann Laboratories, University of Queensland, St. Lucia, Queensland 4072, Australia. Accepted for publication 19 April 2000.

\begin{abstract}
Geering, A. D. W., McMichael, L. A., Dietzgen, R. G., and Thomas, J. E. 2000. Genetic diversity among Banana streak virus isolates from Australia. Phytopathology 90:921-927.

Banana streak virus (BSV) is an important pathogen of bananas and plantains (Musa spp.) throughout the world. We have cloned and sequenced part of the genomes of four isolates of BSV from Australia, designated BSV-RD, BSV-Cav, BSV-Mys, and BSV-GF. These isolates originated from banana cvs. Red Dacca, Williams, Mysore, and Goldfinger, respectively. All clones contained a sequence covering part of open reading frame III and the intergenic region of the badnavirus genome. The sequences were compared

that of BSV-Onne, differing by only two nucleotides over 1,292 bp. However, BSV-Cav, -Mys, and -GF were divergent in nucleotide sequence. Phylogenetic analyses using conserved sequences in the ribonuclease $\mathrm{H}$ domain revealed that all BSV isolates were more closely related to each other than to any other badnavirus. BSV-Cav was most closely related to BSV-Onne, and there was $95.1 \%$ identity between the two amino acid sequences. Other relationships between the BSV isolates were less similar, with sequence identities ranging from 66.4 to $78.2 \%$, which is a magnitude comparable to the distance between some of the recognized badnavirus species. Immunocapture-polymerase chain reaction assays have been developed, allowing specific detection and differentiation of the four isolates of BSV.
\end{abstract} with those of other badnaviruses, including BSV-Onne, a previously characterized isolate from Nigeria. The BSV-RD sequence was virtually identical to

Banana streak disease was first reported from the Ivory Coast in 1968 (20). The most characteristic disease symptoms on the leaves of bananas and plantains (Musa spp.) are chlorotic and necrotic streaks, which tend to be intermittent in expression (20). Diseased plants may be stunted, and fruit may be distorted with a thinner peel and occur in smaller bunches (18). On occasions, heart rot of the pseudostem and plant death have also been noted (20). Banana streak virus (BSV), the causal agent of the disease, was first isolated and characterized from banana in Morocco (19). BSV has since been detected in many banana and plantain production areas of South and Central America, Africa, China, India, Southeast Asia, and the Pacific (20).

BSV is a member of the family Caulimoviridae, genus Badnavirus (29). Badnaviruses have bacilliform-shaped virions, $\approx 30 \times$ $150 \mathrm{~nm}$ in size and a circular, noncovalently closed dsDNA genome (20). All badnaviruses have three open reading frames (ORFs). A single transcriptional promoter, analogous to the $35 \mathrm{~S}$ promoter of Cauliflower mosaic virus, is present in the intergenic region between the end of ORF III and the beginning of ORF I $(25,35)$. One large polycistronic and terminally redundant RNA is transcribed from the genomic DNA, and ORFs II and III are probably translated via leaky scanning by the ribosome (8). The functions of ORFs I and II are not well understood, although the C terminus of the ORF II protein of Cacao swollen shoot virus (CSSV) has dsDNA- and ssRNA-binding properties (16). ORF III encodes a polyprotein with movement protein, coat protein, aspartic protease, reverse transcriptase (RT), and ribonuclease $\mathrm{H}$ (RNase H) functions (14). This polyprotein is thought to be posttranslationally cleaved into functional units by the aspartic protease.

Corresponding author: A. D. W. Geering; E-mail address: geerina@dpi.qld.gov.au

Publication no. P-2000-0627-01R

(C) 2000 The American Phytopathological Society
Additional keyword: Banana streak disease.

BSV is genomically and serologically very variable. Based on polymerase chain reaction (PCR) amplification with degenerate primers, followed by DNA hybridization assay, four distinct isolates of BSV were identified in a previous study (21). The complete genome of one isolate of BSV from Nigeria (BSV-Onne) recently has been sequenced and is 7.4-kb long (11). In most respects, BSV-Onne is typical of other characterized badnaviruses. Proteins encoded by BSV-Onne have the closest sequence identity to those of Commelina yellow mottle virus (ComYMV; 11).

One remarkable feature of BSV-Onne is that it is integrated into the chromosomal DNA of some Musa genotypes $(12,27)$. The integrant that has been found in cv. Obino L'Ewai (Musa AAB group) contains a sequence representing the complete genome of the virus. However, the sequence is interspersed with a 6,091-bplong "scrambled" region consisting of several segments of noncontiguous viral sequence in both direct and inverted orientations. Infection is thought to arise from episomal expression of this integrant. The current model for episomal expression of the integrant involves two homologous recombinations, leading to excision of the scrambled region and circularization of the DNA to form a transcriptionally active form of the virus (27). Tissue culture has been implicated in triggering expression of the integrant (27).

Based on current knowledge, only BSV-Onne is considered to arise from integrated sequences. Sugarcane bacilliform virus (SCBV) has been experimentally transmitted to bananas and in this host elicits symptoms typical of banana streak disease $(3,20)$. Therefore, cases of banana streak disease could arise from transmission of badnaviruses from sugarcane to bananas.

The great variability found in BSV makes reliable detection difficult. In this paper, we describe properties of four isolates of BSV found infecting bananas in Australia. Specific immunocapture (IC)-PCR assays have been developed for each of these virus isolates. Through a better understanding of the genetic diversity of BSV in Australia, it is hoped that diagnostic tests will be improved to allow better virus-indexing procedures, which will in 
turn help to provide a better understanding of the epidemiology of the virus.

\section{MATERIALS AND METHODS}

Virus isolates. Banana plants with chlorotic and necrotic streak symptoms suggestive of BSV infection were sampled at four locations in north Queensland, Australia. Sampled cultivars included Red Dacca (Musa AAA group) from Gordonvale (BSV-RD), Williams (Musa AAA group, Cavendish subgroup) from Innisfail (BSV-Cav), Mysore (Musa AAB group, Mysore subgroup) from South Johnstone (BSV-Mys), and Goldfinger (Musa AAAB group, synonym FHIA 1) from Deeral (BSV-GF). Leaf samples were used fresh, preserved by freeze-drying, or frozen at $-70^{\circ} \mathrm{C}$.

Virus purification. Small-scale, partial purifications of BSV (virus minipreps) were done using a modified method of Ahlawat et al. (2). Samples of lamina tissue $(2 \mathrm{~g})$ powdered in liquid nitrogen were extracted with $6 \mathrm{ml}$ of $0.2 \mathrm{M}$ potassium phosphate, $\mathrm{pH} 7.0$, with $15 \mathrm{mM}$ EDTA, 2\% (wt/vol) polyvinylpyrrolidone (PVP)-40, 2\% (wt/vol) polyethylene glycol (PEG) 6000, and $0.4 \%$ (wt/vol) sodium sulfite (miniprep buffer). The extract was filtered through four layers of cheesecloth, fibers were reextracted with $2 \mathrm{ml}$ of miniprep buffer, and filtrates were combined. The extract was centrifuged at $12,000 \times g$ for $15 \mathrm{~min}$ at $5^{\circ} \mathrm{C}$. Following addition of Triton X-100 to a final concentration of $2 \%$ (vol/vol), the supernatant was layered over a $1-\mathrm{ml}$ pad of $30 \%(\mathrm{wt} / \mathrm{vol})$ sucrose in 0.2 $\mathrm{M}$ potassium phosphate, $\mathrm{pH} 7.0$, and centrifuged at 121,000 $\times \mathrm{g}$ for $30 \mathrm{~min}$ at $5^{\circ} \mathrm{C}$. The pellet was rinsed with distilled water and resuspended in $100 \mu \mathrm{l}$ of $0.01 \mathrm{M}$ potassium phosphate, $\mathrm{pH}$ 7.0. The virus preparation was extracted with $30 \mu \mathrm{l}$ of chloroform, and the aqueous phase was retained for further analysis.

Full purifications of BSV-Mys were done according to the method of Adomako et al. (1) with the following modifications. Lamina tissue was extracted with 8 vol of $0.05 \mathrm{M}$ sodium phosphate, $\mathrm{pH} 6.1$, containing $5 \mathrm{mM}$ sodium diethyldithiocarbamate, $0.2 \%$ (vol/vol) thioglycerol, $0.5 \%$ (wt/vol) PEG 6000, and $0.5 \%$ (vol/vol) celluclast (Novo Nordisk, Bagsvaerd, Denmark). The PEG precipitate was pelleted by centrifugation at $10,000 \times g$ for $20 \mathrm{~min}$ at $10^{\circ} \mathrm{C}$, and the pellet was resuspended in $1 / 30$ of the original extraction volume of $0.05 \mathrm{M}$ sodium phosphate, $\mathrm{pH} 6.8$, containing $0.2 \mathrm{M}$ sodium chloride, $0.1 \%$ (wt/vol) sodium sulfite, and $5 \mathrm{mM}$ EDTA. The eluates from each celite filtration step were centrifuged at $7,000 \times g$ for $10 \mathrm{~min}$ at $10^{\circ} \mathrm{C}$, and the supernatants were centrifuged at $25,500 \times g$ for $50 \mathrm{~min}$ at $5^{\circ} \mathrm{C}$. The pellets were resuspended in $100 \mu \mathrm{l}$ of $0.02 \mathrm{M}$ sodium citrate, $\mathrm{pH} 7.0$, and an aliquot was stained with $2 \%$ potassium phosphotungstate (KPT), $\mathrm{pH} 7.0$, and examined by electron microscopy for the presence of virions. Preparations containing high virion titers were pooled and layered onto a 10 to $40 \%$ sucrose density gradient in citrate buffer and centrifuged at 35,000 rpm for $1 \mathrm{~h}$ in a SW 41 rotor (Beckman Coulter, Fullerton, CA). The gradients were fractionated with a density gradient fractionator (ISCO Inc., Lincoln, NE), and fractions containing virions were pooled, diluted in citrate buffer, and pelleted by centrifugation at $29,000 \times g$ for $30 \mathrm{~min}$ at $5^{\circ} \mathrm{C}$. Pellets were resuspended in $50 \mu \mathrm{l}$ of citrate buffer, and an aliquot was stained with KPT and examined by electron microscopy for virion concentration and purity.

Immunosorbent electron microscopy. Virus minipreps were examined by immunosorbent electron microscopy (ISEM) as described by Thomas (33) with the following modifications. Grids were coated with a 1:1,000 dilution of broad-spectrum antiserum made to a mixture of BSV and SCBV isolates (antiserum PMX2RC; 26) and viewed under a $\mathrm{H}-7000$ transmission electron microscope (Hitachi Denshi Ltd., Tokyo).

Cloning, sequencing, and sequence analyses. Genomic DNA of BSV-Mys was extracted from purified virions according to the method of Lot et al. (22). The DNA was digested with XhoII, the fragments ligated into Bam HI-cut pBluescript vector $\mathrm{SK}(+)$ (Stratagene Inc., La Jolla, CA), and the recombinant plasmids transformed into E. coli strain DH5 $\alpha$ (Life Technologies Inc., Rockville, MD). PCR-amplified DNA fragments of BSV-RD, -Cav, and -GF were cloned with a Topo TA Cloning Kit (Invitrogen Corp., Carlsbad, CA) according to the manufacturer's instructions. Plasmid DNA was purified using either the alkaline lysis method (31) or a Bresapure plasmid mini-kit (GeneWorks, Adelaide, Australia) and sequenced with fluorescent dye terminators on an automatic sequencer (Perkin-Elmer Applied Biosystems Inc., Foster City, CA). To account for sequence errors introduced during PCR, at least three clones of each BSV isolate were sequenced, and a consensus sequence was determined. Sequence analyses were done with programs housed at the Australian National Genomic Information Service, University of Sydney. Database searches were done using FASTA (28). Sequences were aligned using CLUSTAL W (34), and the percent identity of pairwise combinations of aligned sequences calculated with the program DISTANCES (Genetic Computer Group Inc., Madison, WI). Phylogenetic analyses were done using the PHYLIP software package (J. Felsenstein, University of Washington, Seattle). Trees were created using either the parsimony method (PROTPARS) or the neighbor-joining method (NEIGHBOR), with a distance matrix created with PROTDIST. Robustness of the tree was determined by bootstrap sampling of the multiple sequence alignment (1,000 sets) with the program SEQBOOT, and a consensus tree was generated with CONSENSE. Primers were designed with the program PRIME (Genetics Computer Group). Sequences of BSV-RD, -Cav, -Mys, and -GF have been deposited in GenBank as Accession Nos. AF215816, AF215815, AF214005, and AF215814, respectively. Additional sequences for analyses were obtained from GenBank, and are as follows (GenBank Accession Nos. are given in parentheses): BSV-Onne (AJ002234), ComYMV (X52938), CSSV (L14546), Dioscorea bacilliform virus sequence variants 'a' (DBV', X94576 and X94581) and 'b' (DBV tungro bacilliform virus (RTBV, D10774), and SCBV (M89923).

Primers and PCR. BADNA3 and BADNAT primers (21), designed from conserved regions of the badnavirus genome (RNase $\mathrm{H}$ motif and tRNA ${ }^{\mathrm{MET}}$ binding site, respectively), were used to

TABLE 1. Sequences of polymerase chain reaction (PCR) primers and predicted sizes of PCR products

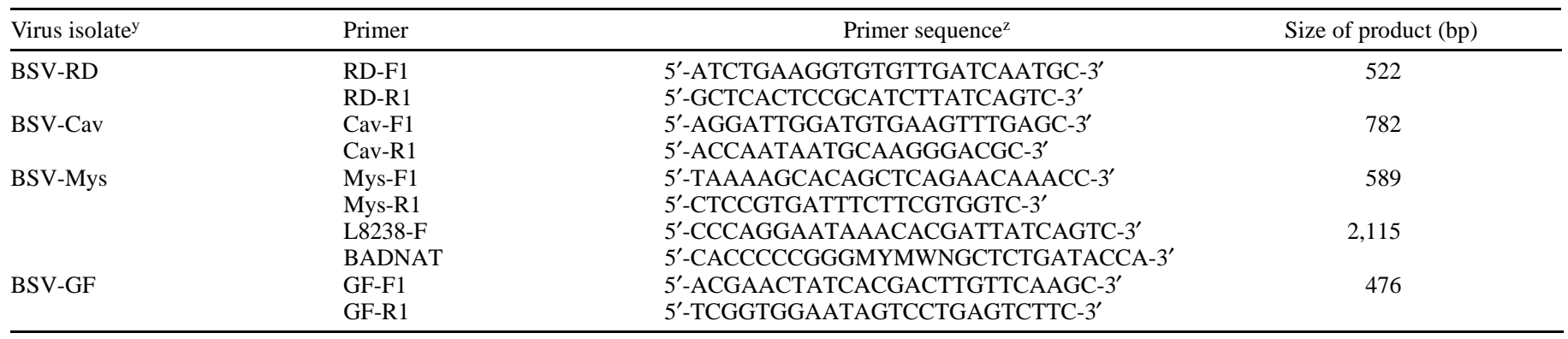

y Virus isolate from which sequence was obtained for primer design.

${ }^{\mathrm{z}}$ Positions of degenerate nucleotides indicated by the following codes: $\mathrm{N}=\mathrm{A}, \mathrm{C}, \mathrm{G}$, or $\mathrm{T} ; \mathrm{M}=\mathrm{A}$ or $\mathrm{C}$; W $=\mathrm{A}$ or $\mathrm{T}$; and $\mathrm{Y}=\mathrm{C}$ or $\mathrm{T}$. 
amplify DNA from BSV-RD, -Cav, and -GF. PCR mixes (25- or 50- $\mu$ l final volume) contained 2 units of Taq DNA polymerase (Life Technologies), $1 \times$ polymerase buffer, $50 \mu \mathrm{M}$ each dNTP, 0.4 $\mu \mathrm{M}$ each primer, and $1.5 \mathrm{mM} \mathrm{MgCl}_{2}$. Amplification conditions were four cycles at $94^{\circ} \mathrm{C}$ for $30 \mathrm{~s}, 37^{\circ} \mathrm{C}$ for $30 \mathrm{~s}$, and $72^{\circ} \mathrm{C}$ for $2 \mathrm{~min}$, followed by 30 cycles at $94^{\circ} \mathrm{C}$ for $30 \mathrm{~s}, 55^{\circ} \mathrm{C}$ for $30 \mathrm{~s}$, and $72^{\circ} \mathrm{C}$ for $2 \mathrm{~min}$.

BSV-Mys DNA was amplified using L8238-F (Table 1) and BADNAT primers. A 50- $\mu$ l PCR mix contained 2 units of Taq DNA polymerase, $1 \times$ polymerase buffer, $200 \mu \mathrm{M}$ each $\mathrm{dNTP}, 0.4 \mu \mathrm{M}$ each primer, and $1.25 \mathrm{mM} \mathrm{MgCl}_{2}$. Amplification conditions were 1 cycle at $94^{\circ} \mathrm{C}$ for $30 \mathrm{~s}$, followed by 35 cycles at $94^{\circ} \mathrm{C}$ for $30 \mathrm{~s}, 55^{\circ} \mathrm{C}$ for $30 \mathrm{~s}$, and $72^{\circ} \mathrm{C}$ for $2 \mathrm{~min}$.

Specific PCR assays for each virus isolate were done with the primers shown in Table 1 . A $25-\mu 1$ reaction mix contained 1 unit of Taq DNA polymerase, $1 \times$ polymerase buffer, $100 \mu \mathrm{M}$ each dNTP, $0.1 \mu \mathrm{M}$ each primer, and $2.0 \mathrm{mM} \mathrm{MgCl}_{2}$. For the RDF1/R1, Mys-F1/R1, and GF-F1/R1 PCRs, the amplification con-

\section{A. Reverse transcriptase}

BSV-Onne
BSV-Mys
ComYMV
CSSV
DBV $^{\text {a }}$
DBV $^{\text {b }}$
SCBV
RTBV

BSV-Onne
BSV-Mys
COMYMV
CSSV
DBV
DBV
SCBV
RTBV

\section{B. Ribonuclease $\mathbf{H}$}

BSV-Onne
BSV-Cav
BSV-Mys
BSV-GF
ComYMV
CSSV
DBV
DBV
SCBV
RTBV

BSV-Onne
BSV-Cav
BSV-Mys
BSV-GE
COmYMV
CSSV
DBV
DBV
SCBV
RTBV
BTS
BSV-Onne
BSV-Cav
BSV-Mys
BSV-GF
COmYMV
CSSV
DBVa
DBV
SCBV
RTBV

KERLVFNYKRLNDNTEKDQYSLPGINTIIKRIGNAK YYKFDLKSGFHQYAMDPESIPWT KERLVFN FKRIJNDNTEKDQYSIPGINTIISRIGNAK VYSKEDLKSGFHQVAMDPESIPWT KERMVFNYKLLNENTESDQYSLPGINT I I SKVGRSK IYSKEDLKSGFWQVAMEEESVPWT KERLVFNYKRLNDNTEKDQYSLPGIQTILKRVGNKKVFSKFDLKSGEHQVAMAEESIPWT KETMVENYKRLNDNTEKDQYSLPGINTILKRVGNSK YYSKFDLKSGEHQVAMHPDSIQWT KERMVENYKRLNDNTEKDQYSLPGINTILKKVGNMKIYSKEDLKSGEHQVAMHPDSIQWT KPRLVENYKRLNDNTWPDQYSLPGINALLKNVARAKIIFSKEDLKSGEHQVAMDEESI PLT KPRIVYNYKRLNDNMHTDPFNIPHKI SMINLIQRANIESKFDLKAGFHHMKLKDDFKDWT ${ }^{*}::^{*}:{ }^{*}:^{*} *:^{*} \quad::::^{*}::^{* * * * * *}:{ }^{*}::::^{*}$

AFWAIDGLY WLVMPEGLKNAPAIEQRKMDNCERGTEDEIAVYIDDIIVFGE AFLANNELYEWLVMPEGLKNAPAIE QRKMDTCFKGTEAFIAVYIDDILVFSE AFLAGNKLY DWLVMP FGLKNAPAI FRKMDNVFKGTAKFIAVYIDDILVFSE AFWVPQGLY AFCVPGGLYEWLVMP FGLKNAPAVH QRKMDNCFRGTEDFIAVYIDDILVESR AFCVPGGLY EWLVMP FGLKNAPAV ARKMDGCFRGT ADFIAVYFDDILVFSR AFSAYNELY WWLVMP FGLKNAPAIE QRKMDQCFRGTE GEIAVYIDDILVESE TFTCSEGLYTWNVCPEGIANAPCAEQRFMQESF-GDT KFALLYIDDILIASN

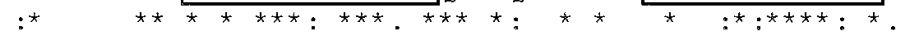

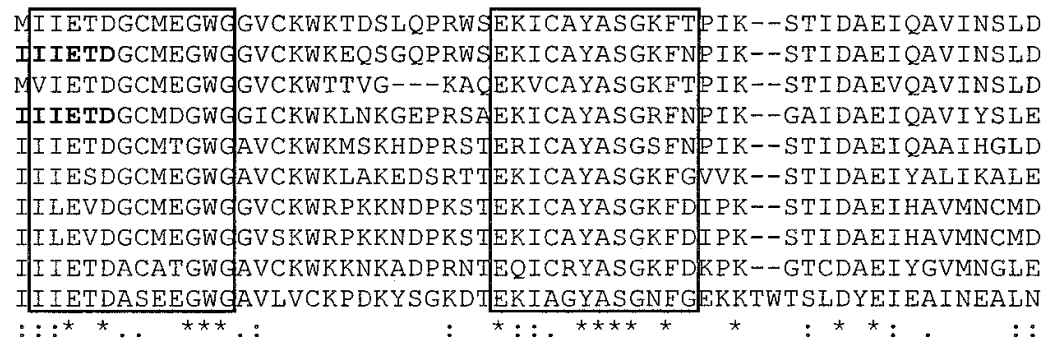

KFKIYYLDKKELI IRTDSQA IVS FYKKSSDHKPSRVRWLAFTDYITGTGLEIKFEGIDGK KEKIYYLDKKELIIRTDSQAIVSFYKKS SDHKPSRVRWLAFTDYITGTGLDVKFEHIDGK KEKIYYLDKKELLIRTDCEAIVRFYKSTAQNKPSRVRWLMLTDFISGTGLEIKEEHINGC KEKIYYLDKKELILRTDSKA IVRFYEKCSEHKP SRVRWMTLTDYI SGCGVKVYEEHIDGK KFKIYYLDKKELI IRSDCEAIIKFYNKTNENKPSRVRWLTFSDFLTGLGITVTEEHIDGK SFKIEYLDKKHLVVRTDCOAIVT FYNKTSTHKDSRIRWITFSDYITGLGVPVTIEHIDGK KE'KIHYLDKKELLIRTDCQATMAFYNKSSCNKP SRVRWIAFNDFLTGLGI PVTIEHIDGK KFKIHYLDKKELITRTDCHAIMAFYNKS SCNKPSRVRWIAFNDELTGLGIPVTIEHIDGK KMRLEYLDKREITVRTDSSAI ERFYNKSAEHKPSEIRWIRFMDYITGAGPEIVIEHIKGK KEQI-YIDK-DETIRTDCEAIVKGIKTEDYKKRSKTRWIKLRDNLLKDGYKPTEEHIKGN

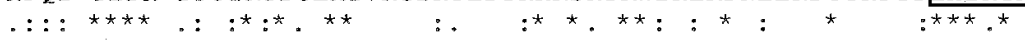

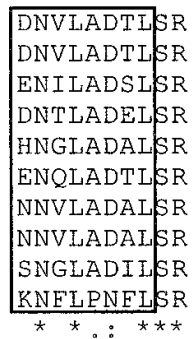

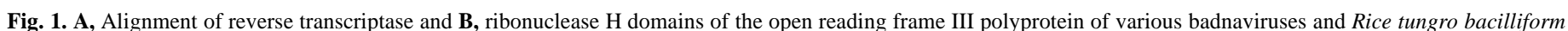

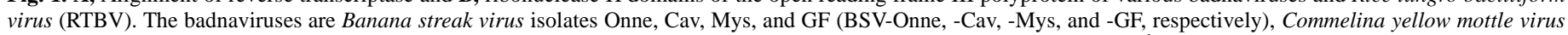

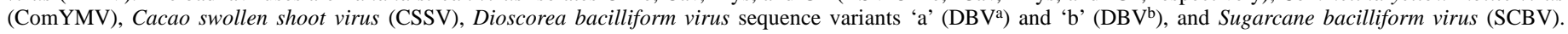

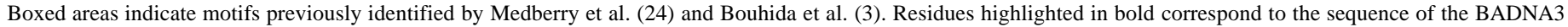
primer. An asterisk denotes an exact match, and double or single dots denote positions of conserved or semiconserved amino acid changes, respectively. 
ditions were 1 cycle at $94^{\circ} \mathrm{C}$ for $30 \mathrm{~s}, 35$ cycles at $94^{\circ} \mathrm{C}$ for $10 \mathrm{~s}$, $64^{\circ} \mathrm{C}$ for $30 \mathrm{~s}$, and $72^{\circ} \mathrm{C}$ for $1 \mathrm{~min}$. The Cav-F1/R1 PCR amplification conditions were the same as for the other specific PCRs, except primer annealing was done at $60^{\circ} \mathrm{C}$ for $30 \mathrm{~s}$.

IC-PCR. Thin-walled PCR tubes were coated at room temperature for 2 to $3 \mathrm{~h}$ with $25-\mu \mathrm{l}$ solutions of SCBV or BSV immuno-

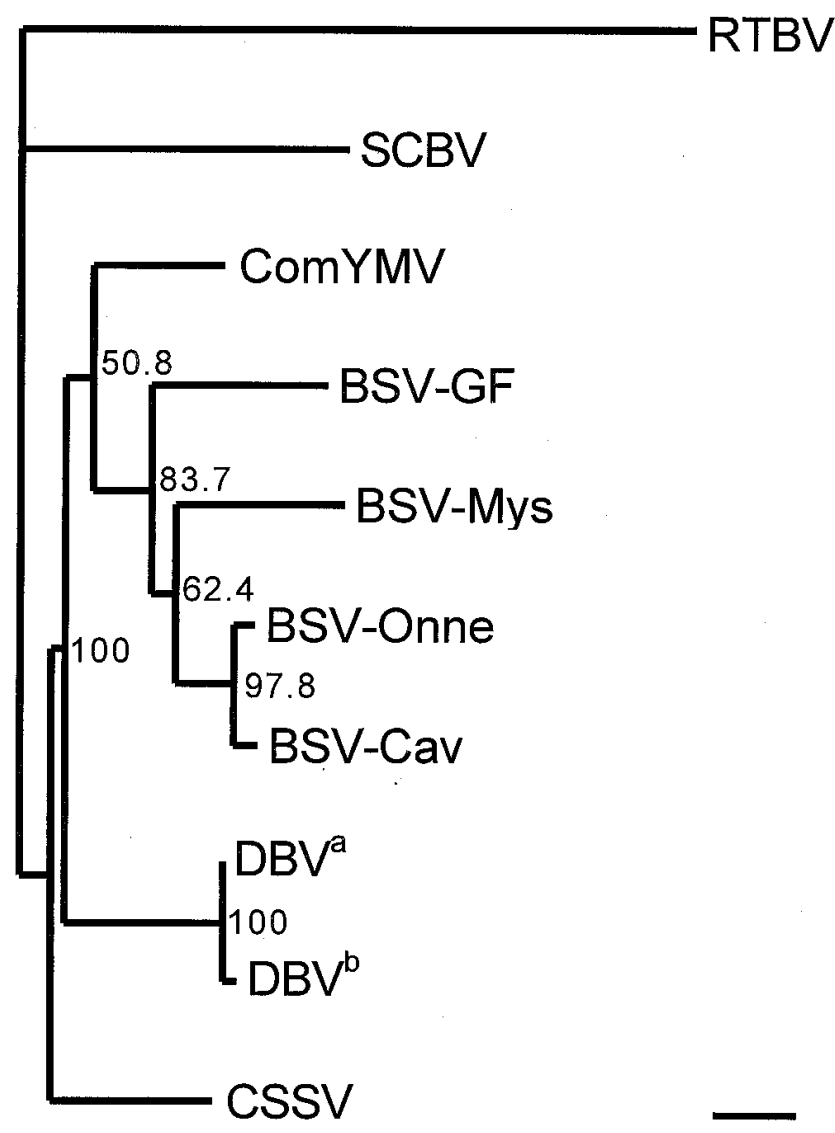

Fig. 2. Additive tree depicting the relationships of the various badnaviruses and Rice tungro bacilliform virus (RTBV), based on the alignment of the ribonuclease $\mathrm{H}$ domain of the open reading frame III polyprotein shown in Figure 1B (excluding the sequence corresponding to the BADNA3 priming site). The badnaviruses are Banana streak virus isolates Onne, Cav, Mys, and GF (BSVOnne, -Cav, -Mys, and -GF, respectively), Commelina yellow mottle virus (ComYMV), Cacao swollen shoot virus (CSSV), Dioscorea bacilliform virus sequence variants ' $a$ ' $\left(\mathrm{DBV}^{\mathrm{a}}\right)$ and ' $\mathrm{b}$ ' $\left(\mathrm{DBV}^{\mathrm{b}}\right)$, and Sugarcane bacilliform virus (SCBV). Horizontal branch length is proportional to genetic distance; the scale bar in the bottom right corner represents 0.1 substitutions per position in the alignment. Bootstrap values of $\geq 50 \%$ are shown at the nodes of the branches. globulin (Ig)G (Agdia CAB 72200 and CAB 81800, respectively), at concentrations of $1 \mu \mathrm{g} / \mathrm{ml}$ in $0.05 \mathrm{M}$ sodium carbonate buffer, $\mathrm{pH}$ 9.6, or PMX2RC antiserum (26), at a 1:1,000 dilution in the same buffer. Following the antibody incubation, the tubes were washed twice by vortexing with $50-\mu$ l lots of phosphate-buffered saline (PBS) containing $0.05 \%$ Tween 20 (vol/vol; PBST).

To prepare leaf extracts for testing by IC-PCR, $0.2 \mathrm{~g}$ of leaf material was ground in a mortar and pestle with acid-washed sand

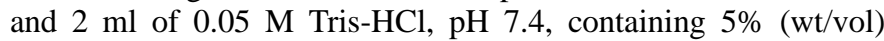
skim milk powder and $0.5 \%$ (wt/vol) sodium sulfite. The leaf extract was clarified by centrifuging at $10,000 \times g$ for $2 \mathrm{~min}$, and $25 \mu \mathrm{l}$ of the supernatant or an equivalent volume of virus miniprep was added to the tubes and incubated overnight at $4^{\circ} \mathrm{C}$. The tubes were washed with $50 \mu \mathrm{l}$ of PBST three times ( 3 min per wash). The tubes were rinsed with $50 \mu$ of water, PCR mix was added, and tubes were subjected to the appropriate thermal cycling conditions, as described above.

Negative PCR controls included leaf tissue from healthy plants of cvs. Red Dacca, Williams, and Goldfinger. Cv. Mysore is considered to be $100 \%$ infected with BSV, and therefore, healthy $\mathrm{cv}$. Pisang Ceylan (Musa AAB group, Mysore subgroup) was included in tests as a negative control.

Detection of PCR-amplified DNA fragments. PCR-amplified DNA fragments were routinely detected by gel electrophoresis. Ten microliters of the completed PCR was loaded onto a $1 \%$ agarose gel in $0.5 \times$ Tris-borate-EDTA (TBE), run at $100 \mathrm{~V}$ for 70 to $80 \mathrm{~min}$, and the gel was stained with ethidium bromide (31).

PCR-amplified DNA fragments were detected by microtiter plate assay according to the method of Hataya et al. (13) with the following modifications (32). Digoxygenin (DIG)-labeled probes were prepared by PCR with the same primers used to amplify the target viral DNA. PCR mixes contained dATP, dCTP, and dGTP at a concentration of $100 \mu \mathrm{M}$, whereas dTTP and DIG-dUTP (Roche Diagnostics, Basel, Switzerland) were at concentrations of 95 and $5 \mu \mathrm{M}$, respectively. Template was $1 \mathrm{ng}$ of cloned virus DNA. Probes were gel-purified using a Qiaex II gel extraction kit according to the manufacturer's instructions (Qiagen, Hilden, Germany). All reaction volumes were $100 \mu$ l. Heat-denatured PCR product was diluted 1:200 in $10 \times \mathrm{SSC}(1 \times \mathrm{SSC}$ is $0.15 \mathrm{M} \mathrm{NaCl}$ plus $0.015 \mathrm{M}$ sodium citrate), containing $10 \mathrm{mM}$ EDTA, loaded into the wells of a microtiter plate (Nunc-Immuno Maxisorp; Nalge Nunc International, Rochester, NY). Heat-denatured probe was diluted 1:1,000 in DIG Easy Hyb buffer (Roche Diagnostics). Hybridization was done overnight at $48^{\circ} \mathrm{C}$. Following hybridization, wells were rinsed once with $0.1 \times \mathrm{SSC}$, followed by three $15 \mathrm{~min}$ washes with $150 \mu \mathrm{l}$ of $0.1 \times \mathrm{SSC}$ at $65^{\circ} \mathrm{C}$. Absorbance at $405 \mathrm{~nm}\left(A_{405 \mathrm{~nm}}\right)$ was measured with a Benchmark Microplate Reader (Bio-Rad Laboratories, Hercules, CA).

TABLE 2. Amino acid sequence identity of pairwise combinations of badnaviruses ${ }^{y}$ and Rice tungro bacilliform virus (RTBV) for a portion of the open reading frame (ORF) III polyprotein

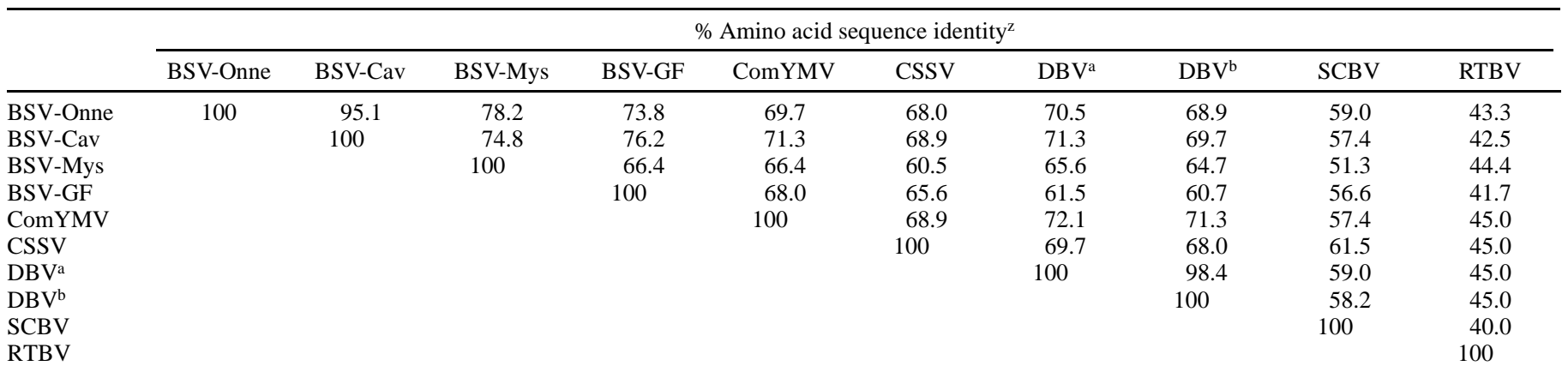

y The badnaviruses are Banana streak virus (BSV) isolates Onne, Cav, Mys, and GF (BSV-Onne, -Cav, -Mys, and -GF, respectively), Commelina yellow mottle virus (ComYMV), Cacao swollen shoot virus (CSSV), Dioscorea bacilliform virus sequence variants 'a' (DBV') and 'b' (DBVb), and Sugarcane bacilliform virus (SCBV).

${ }^{\mathrm{z}}$ Sequence identity is based on the alignment of the ribonuclease $\mathrm{H}$ domain of the ORF III polyprotein shown in Figure 1B, excluding the sequence corresponding to the BADNA3 primer binding site. 


\section{RESULTS}

Cloning of BSV. Two different strategies were used to clone DNA from BSV isolates. For BSV-Mys, genomic DNA was isolated from purified virions, and digested with XhoII, and fragments were cloned into pBluescript. A second strategy was used for BSV-Cav, -GF, and -RD that employed the amplification of a portion of the viral genome with the degenerate badnavirus primers BADNAT and BADNA3 in IC-PCR. This strategy allowed cloning of DNA from small quantities of tissue (1 to $2 \mathrm{~g}$ ) received as diagnostic specimens.

Cloning of BSV-Mys. One 1.6-kb clone (pMys313) and two smaller clones (pMys18 and pMys37) of $\approx 300$ bp were obtained and mapped to ORF III and the intergenic region of the genome, as determined by database searches. An additional 2.1-kb clone of BSV-Mys (pMys2.1) was obtained by designing a virus-specific primer (L8238-F) with a sequence obtained from pMys313 and pairing it with the BADNAT primer in a PCR assay, with viral genomic DNA as template. The complete sequence of the $2.1-\mathrm{kb}$ insert in pMys 2.1 was determined. Together, the genomic clones overlapped $98 \%$ of the sequence covered by the PCR clone.

$I C-P C R$ and cloning of BSV-RD, -Cav, and -GF. In all cases, IC-PCRs of BSV-RD, -Cav, and -GF were done with virus minipreps as a source of template. Either direct electron microscopy or ISEM confirmed the presence of BSV virions in the minipreps (data not shown). For all three virus isolates, $\approx 1.3-\mathrm{kb}$ DNA fragments were obtained from the IC-PCRs with SCBV IgGs to trap virions. A DNA fragment of $\approx 450 \mathrm{bp}$ was obtained with BSV-RD, but not with the other two virus isolates. For BSV-RD and -Cav, DNA fragments of identical size were obtained when BSV IgGs were used in the IC-PCRs. However, the yield of amplified DNA was less than that obtained in the simultaneous SCBV IC-PCR. No DNA was amplified from BSV-GF with the BSV IC-PCR. However, the yield of amplified DNA from this virus isolate in SCBV IC-PCR was very small, thus the yield of amplified DNA from the BSV IC-PCR may have been too low to be detected by gel electrophoresis.

DNA fragments derived from each of the IC-PCRs were cloned and sequenced. For each virus isolate, clones derived from the SCBV IC-PCR were always the same (>99\% sequence identity) as those derived from the corresponding BSV IC-PCR. The 450-bp clone of BSV-RD was inversely primed with the BADNAT primer, and the sequence of this clone matched the sequence adjacent to the tRNA ${ }^{\mathrm{MET}}$ binding site in the $1.3-\mathrm{kb}$ clone.

Sequence analyses. Sequences of all four BSV isolates had identities close to those of other badnaviruses retrieved in database searches. The sequence of BSV-RD was virtually identical to that of BSV-Onne; over a total length of 1,292 bp, only two nucleotides differed. One difference was located in the intergenic region, and the other was in the ORF III sequence.

As expected, the clones of BSV-RD, -Cav, -Mys, and -GF contained a sequence homologous to ORF III of the badnavirus genome. When the sequences were translated and aligned with the respective region in the genomes of other badnaviruses, conserved motifs were identified, common to the RNase $\mathrm{H}$ domain of all badnaviruses and RTBV (Fig. 1). Furthermore, the additional amino acid sequence of BSV-Mys contained motifs typical of the RT domain.

\begin{tabular}{|c|c|c|c|c|c|}
\hline \multirow[b]{2}{*}{ ComYMV } & TATA Box & \multicolumn{3}{|c|}{ Polyadenylation } & \\
\hline & CCtTATTTAAgCA & $<121 \mathrm{nt}\rangle$ & AATAAA & $<30$ nt $>$ & tRNA ${ }^{\mathrm{MET}}$ \\
\hline BSV-Onne & CtCTATATAAgga & $<57 \mathrm{nt}\rangle$ & AATAAA & $<86 n t>$ & TRNA ${ }^{M E T}$ \\
\hline BSV-Mys & ctCTATATAAggg & $\langle 66 n t>$ & AATAAG & $<99$ nt $>$ & tRNA ${ }^{M E T}$ \\
\hline BSV-Cav & ctcTATAAATagg & $<59 n t>$ & AATAAG & $<98 n t>$ & tRNA ${ }^{M E T}$ \\
\hline $\mathrm{BSV}-\mathrm{GE}$ & gtcTAтAтAAgga & $\langle 154 \mathrm{nt}\rangle$ & & & $t R N A^{M E T}$ \\
\hline
\end{tabular}

Fig. 3. Putative transcriptional elements present in the intergenic region of Banana streak virus (BSV) isolates.
To investigate the relationships of the badnaviruses and RTBV, a phylogenetic analysis was done using the neighbor-joining method. The conserved region of the RNase $\mathrm{H}$ domain is shown in Figure $1 \mathrm{~B}$. The results of this analysis suggest that the BSV isolates are more closely related to each other than to any of the other badnaviruses thus far characterized (Fig. 2). Relationships derived by the parsimony method were identical. BSV-Cav was most closely related to BSV-Onne, and there was $95.1 \%$ identity between the two amino acid sequences (Table 2). Other relationships between the BSV isolates were less similar, with sequence identities ranging from 66.4 to $78.2 \%$, which is a magnitude comparable to the distance between some of the distinct badnavirus species such as ComYMV and DBV. A similar pattern of relationships was found when a larger part of the ORF III polyprotein, covering both the RT and RNase H domains, was compared (data not shown).

The intergenic region between the end of the ORF III polyprotein and the tRNA ${ }^{\mathrm{MET}}$ (BADNAT) priming site in the BSV-Cav, -Mys, and -GF genomes contained a putative TATA box, a component of the badnavirus promoter (Fig. 3). A polyadenylation signal in the form AATAAA was not evident in the BSV-Cav, -Mys, or -GF sequences downstream of the putative TATA box, nor in any other part of the intergenic region. However, a potential signal with a single base substitution (17) was present in the BSV-Cav and -Mys sequences (Fig. 3).

Specific detection of BSV by IC-PCR and microtiter plate assay. DNA fragments of the expected size (Table 1) were ob-
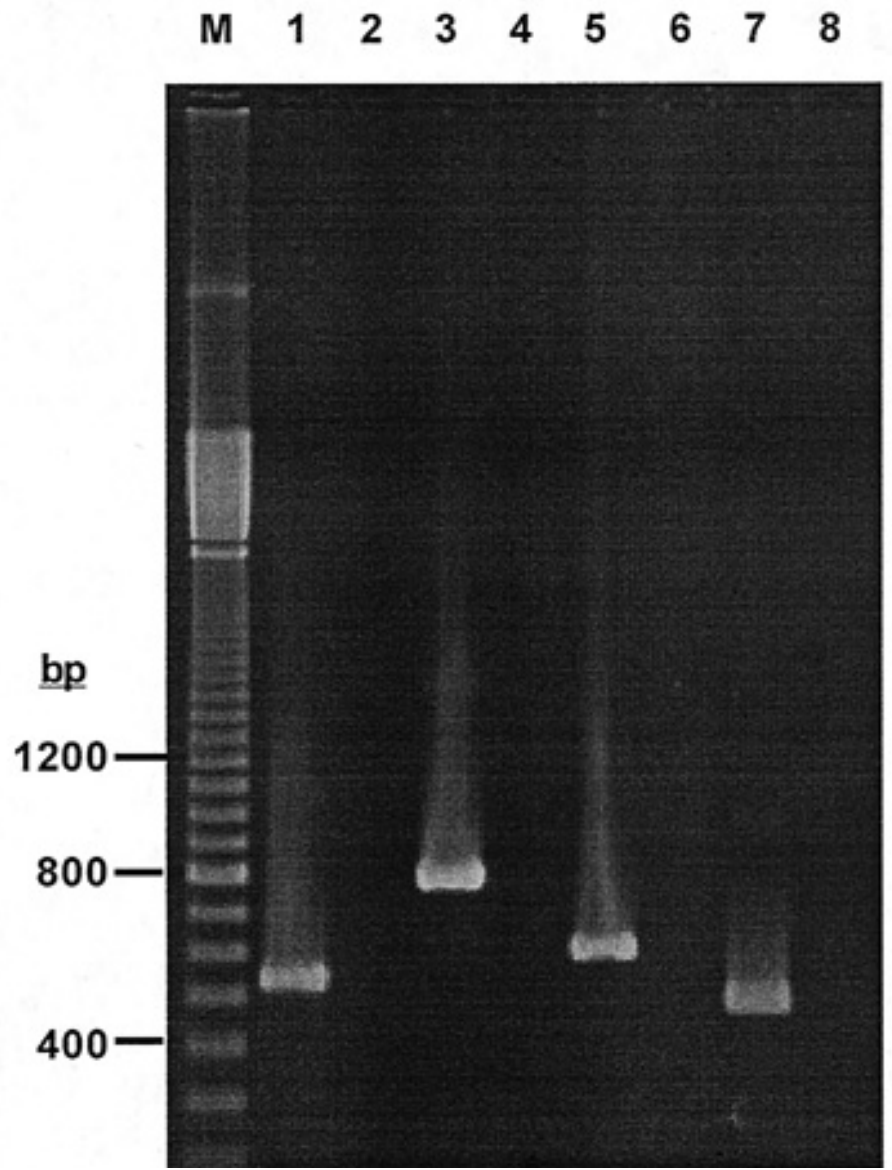

Fig. 4. Immunocapture-polymerase chain reaction detection of Banana streak virus (BSV) isolates. Lanes 1 and 2, leaf extracts of BSV-RD and healthy cv. Red Dacca, respectively, amplified with RD-F1/R1 primers. Lanes 3 and 4, leaf extracts of BSV-Cav and healthy cv. Williams, respectively, amplified with CavF1/R1 primers. Lanes 5 and 6, leaf extracts of BSV-Mys and healthy cv. Pisang Ceylan (Musa AAB group, Mysore subgroup), respectively, amplified with MysF1/R1 primers. Lanes 7 and 8, leaf extracts of BSV-GF and healthy cv. Goldfinger, respectively, amplified with GF-F1/R1 primers. The DNA marker (M) is a 100 -bp ladder. 
tained when IC-PCRs were done for each of the BSV isolates with primers targeted to that particular isolate (Fig. 4). No DNA was amplified from the corresponding healthy controls. Furthermore, when IC-PCRs were done on nontarget BSV isolates, no DNA was amplified (data not shown), indicating that the assays were isolate specific.

A microtiter plate assay was adapted for detection of the amplified DNA fragments. Following a 3-h incubation with enzyme substrate, $A_{405 \mathrm{~nm}}$ values ranging from 1.83 to 2.80 were obtained when amplified DNA fragments were reacted with homologous probes. In comparison, $A_{405 \mathrm{~nm}}$ values for corresponding healthy controls were less than 0.02 . $A_{405 \mathrm{~nm}}$ values for reactions between amplified DNA fragments and heterologous probes were comparable with the healthy controls, indicating the high specificity of the test.

\section{DISCUSSION}

We have provided evidence of genetic diversity among BSV isolates from Australia. The BSV isolate from cv. Red Dacca (BSV-RD) was virtually identical to BSV-Onne, whereas the isolates from cvs. Williams, Mysore, and Goldfinger were divergent in nucleotide sequence. Lockhart and Olszewski (21) described four distinct isolates of BSV that showed significant sequence divergence, based on DNA hybridization analysis. The relationships of our four isolates of BSV to those of Lockhart and Olszewski (21) have not been fully resolved, although initial results suggest that the cv. Mysore isolates from Trinidad and Australia are nearly identical (A. D. W. Geering and B. E. L. Lockhart, unpublished data).

Two types of badnavirus sequence have been found integrated into the Musa genome: the BSV-Onne sequence and a "dead" sequence closely related to CSSV (27). Other badnavirus sequences may also be integrated. We consider it very unlikely that our PCR clones of BSV-RD, -Cav, and -GF were derived from integrated DNA, as in all cases virus minipreps were used as a source of template and DNA was amplified by IC-PCR, favoring amplification of DNA contained within capsids. In a similar BSV IC-PCR, Harper et al. (10) used primer pairs for several Musa "housekeeping" genes and showed that DNA derived from nuclear, mitochondrial, or chloroplast genomes could not be amplified. We did not observe any amplification of DNA from healthy controls in IC-PCR with degenerate or isolate-specific primers.

Circumstantial evidence suggests that the four isolates of BSV are the cause of the disease symptoms we observed in the banana plants. However, the causal relationship between virus and disease symptoms can only be definitively established with infectious clones of viral DNA (3), taking precautions to ensure that virus integrants are not also simultaneously activated (27). Our results suggest that the diseased plants were single infections. However, for BSV-Cav, -RD, and -GF, it is possible that we failed to amplify some types of divergent badnavirus DNA by IC-PCR through failure of the BSV or SCBV IgGs to cross-react with viral capsid proteins or failure of the BADNAT and BADNA3 primers to anneal to the viral DNA.

The results of a phylogenetic analysis using a strongly conserved region of the RNase $\mathrm{H}$ domain of the ORF III polyprotein suggest that the four BSV isolates from Australian banana plants are more closely related to each other than they are to any other badnavirus and the next closest relative is ComYMV. For at least BSV-Mys and BSV-Onne, this result was supported in separate analyses using a longer region of the ORF III polyprotein covering both RT and RNase $\mathrm{H}$ domains. RT and RNase $\mathrm{H}$ sequences commonly have been targeted in studies on the evolution of retroelements, including all reverse-transcribing viruses, as well as retrotransposons $(7,23)$. The $\mathrm{RT}$ and RNase $\mathrm{H}$ domains form part of the gag-pol core replicon, a common component of all retroelements. Different groups of retroelements are thought to have arisen through acquisition of genes, allowing the core replicon to occupy different ecological niches (15). The RT and RNase H sequences are highly conserved, probably because of their enzymatic functions and independent phylogenetic trees derived from each of these sequences are congruent, suggesting a very long association $(7,15,30)$.

Most badnaviruses are relatively recent discoveries, and there are few guidelines on what constitutes strains and species within the genus. When a conserved region of the RNase $\mathrm{H}$ domain of a variety of badnaviruses was compared, previously described species had between 57.4 and $72.1 \%$ amino acid sequence identity. By comparison, the sequence identities of BSV-Onne, -Mys, and -GF ranged from 66.4 to $78.2 \%$, suggesting these three BSV isolates may have diverged into distinct virus species. However, further genomic and biological studies are required to better appraise the taxonomy of the viruses.

BSV-Onne has been widely found in new plantain hybrids developed by Musa breeding programs around the world (5). The occurrence of BSV-Onne in these new hybrids is related to the practice of tissue culture, a process that is considered to activate the viral sequences that are integrated into the host genome (27). It, therefore, is particularly interesting to note that BSV-Onne was found in a cv. Red Dacca plant in Australia. Red Dacca is a cultivar of little commercial interest in Australia and was first introduced into this country during the early 1920s from the Indian subcontinent (6). Cv. Red Dacca subsequently has been multiplied and distributed only by suckers. If the virus infection in this cultivar is derived from an integrated viral sequence in the host DNA, then this result would suggest that factors, additional to tissue culture, can also trigger episomal expression of the virus. However, at this stage, we cannot discount the possibility that infection with BSV-Onne has resulted from mealybug transmission of the virus from another infected plant, perhaps many years ago.

The sources of inoculum from which bananas growing in Queensland have become infected with strains of BSV are obscure. North Queensland is a major sugarcane growing area, and SCBV is widespread within this crop (9). Sugarcane and bananas are often grown in close proximity to each other, and in many cases, land previously cropped with sugarcane has been converted to banana production. It is therefore conceivable that badnavirus has spread between the two crops. Preliminary results suggest that two isolates of SCBV from Australian-grown sugarcane are dissimilar to our BSV isolates, but a third, isolated from a noble cane (Bureau of Sugar Experiment Stations, Queensland, accession no. IJ76-465), has $\approx 90 \%$ nucleotide sequence identity to BSV-Cav (4). It is also possible that, like BSV-Onne, other badnavirus sequences are integrated into the Musa genome and are capable of being activated to give rise to infection. This possibility will be the subject of further investigation.

We have developed specific IC-PCRs for the four isolates of BSV found in Australian bananas. The IC-PCRs will be very useful in future studies for investigating the distribution and epidemiology of these virus isolates.

\section{ACKNOWLEDGMENTS}

This work was supported by the Banana Industry Protection Board and the Horticultural Research and Development Corporation. We thank J. Daniells for provision of leaf material of BSV-Cav and BSV-Mys and B. Lockhart for the kind donation of PMX2RC antiserum.

\section{LITERATURE CITED}

1. Adomako, D., Lesemann, D.-E., and Paul, H. L. 1983. Improved methods for the purification and detection of cocoa swollen shoot virus. Ann. Appl. Biol. 103:109-116.

2. Ahlawat, Y. S., Pant, R. P., Lockhart, B. E. L., Srivastava, M., Chakraborty, N. K., and Varma, A. 1996. Association of a badnavirus with citrus mosaic disease in India. Plant Dis. 80:590-592. 
3. Bouhida, M., Lockhart, B. E. L., and Olszewski, N. E. 1993. An analysis of the complete sequence of a sugarcane bacilliform virus genome infectious to banana and rice. J. Gen. Virol. 74:15-22.

4. Braithwaite, K., Geijskes, J., Geering, A., McMichael, L., Thomas, J., and Smith, G. 1997. Genetic variation in sugarcane bacilliform virus and banana streak virus in Australia. In: Abstr. Pathol. Mol. Biol. Workshop. International Society of Sugar Cane Technologists, Umhlanga Rocks, KwaZulu-Natal, South Africa.

5. Dahal, G., Gauhl, F., Pasberg-Gauhl, C., Hughes, J., d'A, Thottappilly, G., and Lockhart, B. E. L. 1999. Evaluation of micropropagated plantain and banana (Musa spp.) for banana streak badnavirus incidence under field and screenhouse conditions in Nigeria. Ann. Appl. Biol. 134:181-191.

6. Daniells, J. W. 1986. Banana cultivars in Australia. Queensl. Agric. J. 112:75-76.

7. Doolittle, R. F., Feng, D. F., Johnson, M. S., and McClure, M. A. 1989. Origins and evolutionary relationships of retroviruses. Q. Rev. Biol. 64:1-30.

8. Fütterer, J., Rothnie, H. M., Hohn, T., and Potrykus, I. 1997. Rice tungro bacilliform virus open reading frames II and III are translated from polycistronic pregenomic RNA by leaky scanning. J. Virol. 71:7984-7989.

9. Gordon, D. 1996. The properties, diagnosis and control of sugarcane bacilliform virus (SCBV) and sugarcane mild mosaic virus (SCMMV) in Queensland. M.Sc. thesis. University of Queensland, Brisbane, Australia.

10. Harper, G., Dahal, G., Thottappilly, G., and Hull, R. 1999. Detection of episomal banana streak badnavirus by IC-PCR. J. Virol. Methods 79:1-8.

11. Harper, G., and Hull, R. 1998. Cloning and sequence analysis of banana streak virus DNA. Virus Genes 17:271-278.

12. Harper, G., Osuji, J., Heslop-Harrison, J. S., and Hull, R. 1999. Integration of banana streak badnavirus in to the Musa genome: Molecular and cytogenetic evidence. Virology 255:207-213.

13. Hataya, T., Inoue, A. K., and Shikata, E. 1994. A PCR-microplate hybridization method for plant virus detection. J. Virol. Methods 46:223-236.

14. Hohn, T., and Fütterer, J. 1997. The proteins and functions of plant pararetroviruses: Knowns and unknowns. Crit. Rev. Plant Sci. 16:133-161.

15. Hull, R., and Covey, S. N. 1996. Retroelements: Propagation and adaptation. Virus Genes 11:105-118.

16. Jacquot, E., Hagen, L. S., Jacquemond, M., and Yot, P. 1996. The open reading frame 2 product of cacao swollen shoot badnavirus is a nucleic acid-binding protein. Virology 225:191-195.

17. Joshi, C. P. 1987. Putative polyadenylation signals in nuclear genes of higher plants: A compilation and analysis. Nucleic Acids Res. 15:96279640.

18. Lassoudière, A. 1974. La mosaïque dite "à tirets" du bananier Poyo en Côte d'Ivoire. Fruits 29:349-357.

19. Lockhart, B. E. L. 1986. Purification and serology of a bacilliform virus associated with banana streak disease. Phytopathology 76:995-999.

20. Lockhart, B. E. 1995. Banana streak badnavirus infection in Musa: Epidemiology, diagnosis, and control. Food Fert. Tech. Bull. 143.

21. Lockhart, B. E. L., and Olszewski, N. E. 1993. Serological and genomic heterogeneity of banana streak badnavirus: Implications for virus detection in Musa germplasm. Pages 105-113 in: Breeding Banana and Plantain for Resistance to Diseases and Pests. J. Ganry, ed. International Network for the Improvement of Banana and Plantain, Montpellier, France.

22. Lot, H., Djiekpor, E., and Jacquemond, M. 1991. Characterization of the genome of cacao swollen shoot virus. J. Gen. Virol. 72:1735-1739.

23. McClure, M. A. 1995. Molecular evolution of the retroid family. Pages 404-415 in: Molecular Basis of Virus Evolution. A. J. Gibbs, C. H. Calisher, and F. García-Arenal, eds. Cambridge University Press, Cambridge.

24. Medberry, S. L., Lockhart, B. E. L., and Olszewski, N. E. 1990. Properties of Commelina yellow mottle virus's complete DNA sequence, genomic discontinuities and transcript suggest that it is a pararetrovirus. Nucleic Acids Res.18:5505-5513.

25. Medberry, S. L., Lockhart, B. E. L., and Olszewski, N. E. 1992. The Commelina yellow mottle virus promoter is a strong promoter in vascular and reproductive tissues. Plant Cell 4:185-192.

26. Ndowora, T. R. C. 1998. Banana streak virus: Development of an immunoenzymatic assay for detection and characterization of sequences that are integrated in the genome of the host. Ph.D. dissertation. University of Minnesota, St. Paul.

27. Ndowora, T., Dahal, G., LaFleur, D., Harper, G., Hull, R., Olszewski, N E., and Lockhart, B. 1999. Evidence that badnavirus infection in Musa can originate from integrated pararetroviral sequences. Virology 255:214-220.

28. Pearson, W. R., and Lipmann, D. J. 1988. Improved tools for biological sequence comparison. Proc. Natl. Acad. Sci. USA 85:2444-2448.

29. Pringle, C. R. 1998. The universal system of virus taxonomy of the International Committee on Virus Taxonomy (ICTV), including new proposals ratified since publication of the Sixth ICTV Report in 1995. Arch. Virol. 143:203-210.

30. Rothnie, H. M., Chapdelaine, Y., and Hohn, T. 1994. Pararetroviruses and retroviruses: A comparative review of viral structure and gene expression strategies. Adv. Virus Res. 44:1-67.

31. Sambrook, J., Fritsch, E. F., and Maniatis, T. 1989. Molecular Cloning: A Laboratory Manual. 2nd ed. Cold Spring Harbor Laboratory Press, Cold Spring Harbor, NY.

32. Sharman, M., Thomas, J. E., and Dietzgen, R. G. 2000. Development of a multiplex immunocapture PCR with colorimetric detection for viruses of banana. J. Virol. Methods. (In press.)

33. Thomas, J. E. 1986. Purification and properties of ginger chlorotic fleck virus. Ann. Appl. Biol. 108:43-50.

34. Thompson, J. D., Higgins, D. G., and Gibson, T. J. 1994. CLUSTAL W: Improving the sensitivity of progressive multiple sequence alignment through sequence weighting, positions-specific gap penalties, and weight matrix choice. Nucleic Acids Res. 22:4673-4680.

35. Tzafrir, I., Torbert, K. A., Lockhart, B. E. L., Somers, D. A., and Olszewski, N. E. 1998. The sugarcane bacilliform badnavirus promoter is active in both monocots and dicots. Plant Mol. Biol. 38:347-356. 


\section{Erratum}

Vol. 90, No. 8, 2000

In the manuscript entitled "Genetic Diversity Among Banana streak virus Isolates from Australia" by A. D. W. Geering, L. A. McMichael, R. G. Dietzgen, and J. E. Thomas (Phytopathology 90:921-927), the bootstrap value on the phylogenetic tree in Figure 2 is incorrect. The correct phylogenetic tree is shown below.

RTBV

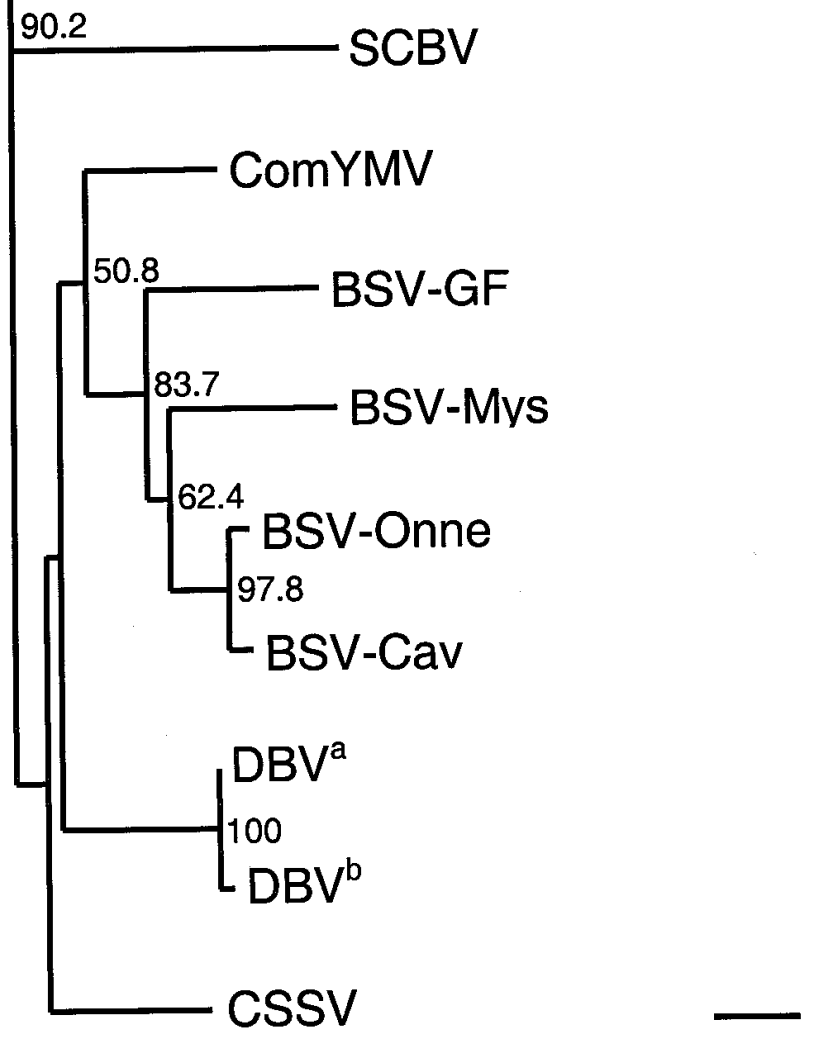

Fig. 2. Additive tree depicting the relationships of the various badnaviruses and Rice tungro bacilliform virus (RTBV), based on the alignment of the ribonuclease $\mathrm{H}$ domain of the open reading frame (ORF) III polyprotein shown in Figure 1B (excluding the sequence corresponding to the BADNA3 priming site). The badnaviruses are Banana streak virus (BSV) isolates Onne, Cav, Mys, and GF (BSV-Onne, -Cav, -Mys, and -GF, respectively), Commelina yellow mottle virus (ComYMV), Cacao swollen shoot virus (CSSV), Dioscorea bacilliform virus sequence variants 'a' $\left(\mathrm{DBV}^{\mathrm{a}}\right)$ and 'b' $\left(\mathrm{DBV}^{\mathrm{b}}\right)$, and Sugarcane bacilliform virus (SCBV). Horizontal branch length is proportional to genetic distance; the scale bar in the bottom right hand corner represents 0.1 substitutions per position in the alignment. Bootstrap values of $\geq 50 \%$ are shown at the nodes of the branches. 